\title{
Snapshots of Current Communication Research in Indonesia
}

\section{Editorial}

You are holding a regional special issue on a selection of hot media topics in contemporary Indonesian society. Some articles in this collection intend to understand Indonesia's current media landscape, its media giants, the mediatized lives of urban, middle-class children in Jakarta, as well as the uses of social media by activists or the female blogosphere and the prominence of technical features to display a public face. Others explore the Muslim identity construction on young Muslim women's blogs, in the home-made television fiction industry, or through the use of (new) media by Muslim religious leaders to reach their community of believers.

This special issue includes in part research presented at the biannual international communication conference held at Universitas Indonesia in December 2012. The double function-scientific value and societal relevance-is what comes as striking for the research in the humanities and social sciences carried out at Indonesian universities. In a young democracy with a weakly developed rational legal authority and with a tradition of clientelism, this combination of action, activism, and making a contribution to change in the media regulatory framework or the agenda of decision-makers, and by extension in people's daily lives, is often the main motivating force behind the research.

The article by Hendriyani, Hollander, d'Haenens \& Beentjes, as part of the $\mathrm{PhD}$ research of the first author, puts empirical research on children and media on the Indonesian map. This study found that urban Jakarta-based middle-class children spend several hours using various media every day. The authors recommend that parents involve their children in making media rules at home. Given that regulation in the area of programs aimed at children is running behind, parents should discuss the potential media effects with their children, including the consequences of excessive use. For the same purpose, parents could use blocking software on computers - a woefully ineffective solution on mobile platforms. One problem is the low ICT literacy levels of most Indonesian parents; teachers tend to be more media-literate. Therefore, teachers could become valuable media literacy education facilitators. Schools in Indonesia are still considered as a highly reliable source of information by both parents and children. This study also found that only few children had a home internet connection. Most children go on the Internet from outside locations, for instance from an Internet café. Schools need to provide equal opportunities for children to learn about computers and the Internet so as to significantly reduce current digital inequalities and make it possible for children to build adequate online skills. The data were collected in 2009 when online platforms and devices such as smart phones were not as popular as today.

Inaya Rakhmani's study looks into the impact of media industrialization in home-made Islamic sinetron (soap operas) on mediated religious expression in Indonesia, by looking at the intersections between religion, morality, authority, and values on the one hand, and media market principles on the other. The author explores contrasting ideological motivations among producers, which have resulted in particular narratives within their content. Common denominator in all narratives is the use of Islamic teachings to address societal issues experienced by middle class Indonesian Muslims. The positioning of the audience as market determines which issues are too sensitive or too confrontative to be represented in Islamic sinetron. The producers' views of the 'audience as market' guide the production of each 
sinetron in different ways. The author raises the question: What kind of image of Islam is being projected on Indonesian television today? The answer is that, owing to risk avoidance and audience maximizaton, social divisions between Muslim groups in Indonesia (e.g. traditionalists, liberals, conservatives) become blurred in Islamic sinetron. The author concludes that such televised images of Islam are inaccurate reflections of religiosity in Indonesia today.

Nurhaya Muchtar and Jeffrey Ritchey criticize the mainstream media's emphases on fundamentalist Muslim clerics. The authors explore in their interviews with moderate Muslim religious leaders what seems to be missing from these media narratives: the efforts by the latter to thwart fundamentalism by improving their communication styles and their uses of media technology in order to reach young people as well as the wider community in an effort to both educate and mentor their followers.

Annisa Beta introduces us into the world of modern urban Indonesian Muslim women in search of moral certainty, spirituality, and piety, enjoying a 'new' Islam in a more personal, pluralistic fashion. These personalized reinterpretations of religious values are further explored in the 'Hijabers' Community, one of the most prominent types of urban Muslims in Indonesia—veiled young women expressing 'fun' and a 'colorful' take on Islam. The Hijaber trend itself is rather new. These women are active users of social network sites such as Facebook, Twitter and Instagram as well as fashion blogs, which all are to be considered as references for sartorial choices and, arguably, for identity constructions among Indonesian youngsters.

Ade Armando turns to the media economics of Indonesia, showing us how the main players in the television industry have constantly hindered broadcasting decentralization and democratization, both under the New Order regime and in the Reform era. All attempts to establish a decentralized commercial television system with a view to the further development of an informed civil society fell short because of the opposition of Jakarta-based major players who constantly sought and found alliances with the Government. Some might argue that the presence of local television stations as part of a large television network would not bring much change considering that these stations will still be under the control of Jakartabased players. Ade Armando challenges this scepticism by arguing that the presence of local television stations would open up opportunities for local journalists who would then become the watchdogs for local institutions. The need for providing local content attracting local audiences would also inevitably give incentives for the station programmers to produce various information programs relevant for building public opinion. Regardless of the interests of Jakarta-based media owners, these local media workers could then build a public sphere in their respective areas.

In her article, Endah Triastuti scrutinizes the Indonesian female blogosphere across the country, and interviews numerous women bloggers in an effort to examine the technical and personalized authoring tools they use in their blogging practices so as to display a public face. She concludes that potential choices are not limitless as they hinge on authors' contexts and even values. It turns out that most Java bloggers in Triastuti's sample favour a 'magazine look' and thus pay for blog hosting. Conversely, in other regions a majority of bloggers are content with the basic nature of free blog platforms. This indicates that technical blog features are anchored contextually. In other words, the technical options used become means to an end. These choices do not always take the best possible advantage of the hybrid nature of blogs. Instead, aware of the infrastructure gap in Indonesia, Java women bloggers adjust their blog's format to maximize readership and reader contributions across the country. 
To conclude this special issue, Effendi Gazali investigates how political communication in Indonesia may (re)formulate at least some aspects of the democratization process in Indonesia thanks to social media use. By the end of 2013, Indonesia had 64 million Facebook users and about 30 million Twitter accounts. Gazali explores the different strategies and tactics activists are following in their attempts to make the most of 'the network of networks', while coping with its limitations. Some activists might still develop good relations with conventional media newsrooms so as to get support for their actions, slogans and summaries launched through social media. Most activists are deeply convinced of the overwhelming influence of social media. Although not always successful, activists have long tried to tactically handle the need to "both embrace the principles of today's consumer culture and challenge the dominant metanarratives" of the mainstream media. According to Gazali, Indonesia keeps moving gradually but significantly towards a so-called 'social media democracy.'

Leen d'Haenens

Ilya Sunarwinadi 